\title{
Meningkatkan Kemampuan Guru Menetapkan Kriteria Ketuntasan Minimal melalui Workshop di SD Negeri 009 Sialang Kubang
}

\author{
Y. SUDIYONO \\ Dinas Pendidikan Kabupaten Kampar \\ Sekolah Dasar Negeri 009 Sialang Kubang - Kampar \\ E-mail : y.sudiyono@yahoo.com
}

\begin{abstract}
Primary school teachers become an important part in order to improve the achievement of efforts to educate the life of the nation. Teachers play an active role in providing learning material, but teachers are also required to be able to understand the real conditions of students especially in terms of setting minimum completeness criteria. Efforts made in order to improve the ability of teachers are inseparable from the policies taken by the principal to involve teachers and facilitate teachers in various activities. In this study, the school principal made a policy by holding a workshop which was given to elementary school teachers, especially SD 009 Sialang Kubang. The research question that was asked whether the workshop was given on the determination of the minimum completeness criteria was able to improve the ability of the teacher in knowledge to set these minimum criteria. Through the school action research method with a survey conducted on the participants' workshops at the workshop as many as 12 people and data collected by distributing questionnaires and also analyzed by descriptive analysis. The results of the classroom action research showed that after the assessment workshop was conducted on the participants' teachers by comparing the previous workshops, information was obtained that there was an increase in the ability of teachers by $23 \%$ in setting minimum completeness criteria. This proves that the implementation of workshops given to teachers is able to improve their ability to set minimum completeness criteria in schools.
\end{abstract}

Keywords: Primary School Teacher Ability, Minimum Completeness Criteria

Berbicara masalah kemampuan guru dalam rangka meningkatkan prestasinya bekerja sebagai guru dan dalam rangka pencapaian kinerja yang menjadi bagian penting dalam pencapaian kinerja sekolah menjadi sebuah kajian yang menarik. Kajian ini menjadi bagian dalam rangka mencerdaskan kehidupan bangsa.

Berbagai literatur menyebutkan arti pentingnya guru dalam pendidikan sebagaimana dijelaskan oleh Mas, S. R. (2008) bahwa "kompetensi profesional guru dalam menciptakan pembelajaran yang berkualitas sangat ditentukan oleh keberhasilan pendidikan secara menyeluruh. yang harus ditunjang oleh kompetensi personal, pedagogik dan kompetensi sosial. Kompetensi-kompetensi tersebut harus dikembangkan dalam proses pembelajaran secara berkesinambungan. Ada empat fungsi guru dalam kepemimpinan di kelas yaitu, sebagai motivator, fasilitator, pemacu maupun pemberi inspirasi. Kualitas guru dapat ditinjau dari dua segi, dari segi proses dan hasil. Terdapat beberapa strategi dan pendekatan yang dapat dilakukan guru agarproses pembelajaran berjalan dengan baik. Strategi tersebut yaitu: menciptakan pembelajaran dengan cara yang demokratis dan iklim yang demokratis, menciptakan pembelajaran yang kooperatif, dan melakukan adaptasi paradigma triplization. Sedangkan pendekatan yang dapat digunakan guru adalah :pendekatan kompetensi, ketampilan proses, lingkungan, contekstual teaching learning (CTL), dan pendekatan temamatik".

Kemudian dijelaskan oleh Sa'ud, U. S. (2000) bahwa: "Upaya peningkatan kualitas sumber daya manusia dan profesionalisme hanya dapat dilakukan melalui peningkatan mutu pendidikan 
nasional. Secara praktis, peningkatan mutu pendidikan merupakan suatu proses yang sinergik dengan upaya peningkatan sumber daya manusia. Ini berarti bahwa peningkatan mutu pendidikan akan terjadi jika kualitas sumber daya manusianya meningkat dan sebaliknya. Keberhasilan upaya peningkatan mutu pendidikan sangat dipengaruhi oleh kualiats sumber daya manusia yang terlibat didalamnya, karena dalam sistem pendidikan apapun, maka kualitas kemampuan dan profesionalisme dari "the man behind the gun"nya merupakan kunci keberhasilan sistem pendidikan. Ini berati bahwa peningkatan kaulitas kemampuan dan profesionalisme tenaga kependidikan merupakan kebutuhan dalam upaya peningkatan mutu pendidikan di era globalisasi ini".

Kemudian juga disampaikan oleh Sadtyadi, H., \& Kartowagiran, B. (2014) bahwa: "Instrumen penilaian kinerja guru sekolah dasar, dalam penelitian ini dikembangkan dengan metode research and development, berdasarkan model pengembangan pembelajaran Borg and Gall yang disesuaikan. Berdasarkan hasil analisis validitas dan reliabilitas, instrumen tersebut valid dan reliabel. Hasil analisis faktor menunjukkan fit model yang cukup baik, berarti dapat disimpulkan bahwa (1) instrumen penilaian kinerja guru sekolah dasar terdiri dari lima komponen yakni mengajar, mendidik, melatih dan mengarahkan, membimbing, serta menilai dan mengevaluasi, (2) masing-masing komponen instrumen penilaian kinerja guru dapat dijabarkan menjadi beberapa indikator relevan seperti yang dideskripsikan dalam hasil penelitian".

Dari pendapat tersebut berkaitan dengan peran guru adalah sangat penting dalam rangka mencerdaskan generasi muda, kemudian juga berbagai cara digunakan untuk meningkatkan profesionalisme guru dalam bekerja dan dalam menghasilkan kinerja yang baik, seperti: memberikan pelatihan dan juga memberikan sosialisasi berbagai kepentingan guru dalam mengajar.
Sebagaimana diketahui bahwa menurut Sudrajat dalam Wahyuni, S., Areva, D., \& Dahen, L. D. (2014). salah satu prinsip pada kurikulum berbasis kompetensi adalah menggunakan acuan kriteria, yakni menggunakan kriteria tertentu dalam menentukan kelulusan peserta didik. Kriteria paling rendah untuk menyatakan peserta didik mencapai ketuntasan dinamakan kriteria ketuntasan minimal.

Kemudian dijelaskan pula bahwa: "KKM harus ditetapkan sebelum awal tahun ajaran dimulai, seberapapun besarnya jumlah peserta didik yang melampaui batas ketuntasan minimal, tidak mengubah keputusan pendidik dalam menyatakan lulus atau tidak lulus pembelajaran. Acuan kriteria mengharuskan pendidikan untuk melakukan tindakan yang tetap terhadap hasil penilaian yaitu memberikan layanan remedial bagi yang belum tuntas atau layanan pengayaan bagi yang sudah melampau KKM. KKM ditetapkan oleh satuan pendidikan berdasarkan hasil musyawarah guru mata pelajaran di satuan pendidikan yang memiliki karakteristk yang hampir sama. Penetapan KKM dilakukan dengan berpedoman kepada kriteria yang ditetapkan oleh Depdiknas. Kriteria tersebut adalalah komplesitas materi, daya dukung sekolah dan intake (kemampuan) siswa. Kriteria-kriteria yang telah ditetapkan harus selalu dipedomani oleh guru dalam menetapkan standar ketuntasan. Hal ini bukanlah suatu yang mudah, dimana guru harus benar-benar memahami ketiga kriteria tersebut serta mempunyai kompetensi dalam menetapkan KKM. Adanya kriteria penetapan KKM tiap sekolah ini akan berbeda'. (Wahyuni, S., Areva, D., \& Dahen, L. D., 2014).

Hal yang terjadi di SD Negeri 009 Sialang Kubang dimana guru dalam rangka menetapkan kriteria ketuntasan minimal kepada mata pelajaran yang diajarkannya kepada siswa masih jauh dari apa yang dirasakan oleh siswa. Maksudnya adalah kondisi siswa tidak menjadi landasan dalam menentukan standar tersebut. Hal inilah 
yang menjadi perhatian dari kepala sekolah dalam rangka mengembangkan kemampuan guru dengan menerapkan workshop atau pelatihan untuk meningkatkan kemampuan guru dalam mengajar dan mencapai ketuntasan mengajar.

Jadi pertanyaan penelitian yang diajukan apakah dengan diterapkannya workshop mengenai kriteria ketuntasan minimal mampu meningkatkan kemampuan guru dalam menetapkan KKM di sekolah oleh guru.

\section{METODE}

Metode penelitian yang digunakan dalam kajian ini adalah metode tindakan yakni dengan menggunakan penelitian tindakan sekolah oleh kepala sekolah. Menurut (Mills, 2003; Stringer, 2004; Glickman etr al., 2007; Hopkins, 2008) dalam Kependidikan, D. T., \& Supervisi, D. P. P. P. maka ciri utama PTS adalah melakukan tindakan nyata untuk memperbaiki keadaan sekolah yang berfokus pada peningkatkan mutu pembelajaran oleh guru yang mampu menghasilkan siswa yang kreatif, inovatif, mampu memecahkan masalah, berpikir kritis, dan bernaluri kewirausahaan.

Teknik pengumpulan data dengan pengamatan dan juga penyebaran pertanyaah yang langsung diberikan dengan menerapkan tindakan pada dua siklus yang dijalankan, dimana pada siklus pertama kepala sekolah mengukur kemampuan guru sebelum diberikannya pelatihan dan siklus kedua setelah diberikannya pelatihan kepada guru dan diberikan kepada guru yang berjumlah 12 orang dalam rangka mengikuti workshop yang diselenggarakan di sekolah dan data dianalisis dengan menggunakan teknik deskriptif.

\section{HASIL}

Berdasarkan hasil penelitian di lapangan berkaitan dengan kemampuan guru dalam menyusun kriteria ketuntasan minimal dalam pembelajaran pelajaran di sekolah dengan menilai capaian penilaian kemampuan yang ada berkaitan dengan dimensi komplesitas materi, dimensi daya dukung sekolah dan dimensi intake (kemampuan) siswa.

Pada siklus pertama yang diperoleh guru sebelum mendapatkan pelatihan yang diberikan kepala sekolah mendapatkan tingkat kemampuan guru dengan nilai ratarata mencapai $65 \%$, dimana dapat dijelaskan kemampuan paling tinggi adalah pada dimensi daya dukung sekolah. Ini bermakna selama ini sekolah sudah sangat mendukung pengembangan guru dalam mengajar di sekolah. Kemudian nilai yang paling rendah berada pada dimensi kemampuan siswa, yang maksudnya adalah guru masih belum maksimal dalam memahami kemampuan siswa dalam mengikuti pelajaran.

Kemudian refleksi yang dilakukan dalam rangka meningkatkan kemampuan guru adalah dengan memberikan penekanan pelatihan pada bagaimana guru mampu menilai kemampuan siswa dalam belajar. Hal ini setelah diberikannya pelatihan maka guru mengalami peningkatan sebesar $23 \%$ atau menjadi $89 \%$ kemampuan siswa dalam menilai kriteria ketuntasan minima. Pada siklus kedua ini menunjukkan bahwa adanya peningkatan dalam bagaimana guru menilai kemampuan siswa, sehingga guru dalam musyawarah menetapkan KKM perlu memperhatikan kemampuan siswanya.

\section{PEMBAHASAN}

Berdasarkan hasil penelitian yang diperoleh di lapangan dapat dengan jelas bahwa selama ini guru masih belum mampu menilai kemampuan siswa dalam menerapkan kriteria ketuntasan minimal. Guru selalu beracuan pada sekolah dengan jenis siswa yang berbeda, dan karena ingin dinilai sekolahnya bagus maka KKM yang diterapkan juga relative tinggi.

Hasil penelitian ini sesuai dengan apa yang disampaikan oleh Aritonang, K. T. (2008) dalam penelitiannya berkenaan dengan minat dan motivasi dalam meningkatkan hasil belajar siswa menjelaskan bahwa " Faktor utama yang mempengaruhi minat dan motivasi belajar adalah cara mengajar guru, karakter guru, 
suasana kelas tenang dan nyaman, dan fasilitas belajar yang digunakan. Selaras dengan temuan yang diperoleh, penelitian ini memberikan saran operasional bagaimana meningkatkan minat dan motivasi belajar siswa".

\section{SIMPULAN}

Berdasarkan uraian tersebut, maka dapat disimpulkan bahwa setelah dilakukannya workshop penilaian dilakukan kepada guru peserta dengan membandingkan sebelumnya mengikuti workshop, maka diperoleh informasi bahwa terjadi peningkatkan kemampuan guru sebesar $23 \%$ guru dalam menetapkan kriteria ketuntasan minimal. Hal ini membuktikan bahwa pelaksanaan workshop yang diberikan kepada guru mampu meningkatkan kemampuannya dalam menetapkan kriteria ketuntasan minimal di sekolah.

\section{DAFTAR RUJUKAN}

Aritonang, K. T. (2008). Minat dan motivasi dalam meningkatkan hasil belajar siswa. Jurnal

Pendidikan Penabur, 7(10), 11-21.

Kependidikan, D. T., \& Supervisi, D. P. P. P. M. Penelitian tindakan sekolah.

Mas, S. R. (2008). Profesionalitas Guru dalam Peningkatan Kualitas Pembelajaran. Jurnal Inovasi, 5(2).

Sa'ud, U. S. (2000). Standarisasi Lulusan dan Program Pendidikan Pra-Jabatan Guru Profesional Sebuah Harapan.

Sadtyadi, H., \& Kartowagiran, B. (2014). Pengembangan instrumen penilaian kinerja guru sekolah dasar berbasis tugas pokok dan fungsi. Jurnal Penelitian dan Evaluasi Pendidikan, 18(2), 290-304.

Wahyuni, S., Areva, D., \& Dahen, L. D. (2014). Proses Penetapan Kriteria Ketuntasan Minimal (Kkm) Pada

Diklat Review: Jurnal Manajemen Pendidikan dan Pelatihan
Mata Pelajaran Ekonomi Kelas X Di Sma Se-Kecamatan Lubuk Kilangan Kota Padang. Jurnal Ipteks Terapan, 8(3), 105-111. 